\title{
Penerapan Metode Pembelajaran Inkuiri Dalam Upaya Meningkatkan Hasil Belajar Siswa Pada Tema Kewajiban dan Hakku Di Kelas III SD Negeri 206/X Pandan Jaya
}

\author{
Elizarita \\ SDN 206/X Pandan Jaya \\ JL. Diponegoro NO. 01, Pandan Jaya, Jambi, Indonesia \\ elizarita@gmail.com
}

\begin{abstract}
This study aims to disclose information and discuss the application of inquiry learning methods in an effort to improve student learning outcomes on the theme of my obligations and rights in third grade at SD Negeri 206/X Pandan Jaya. This research is included in the type of classroom action research (CAR). This research was carried out in this research was carried out at SD Negeri 206/X Pandan Jaya. The time of this research was carried out in the odd semester of the academic year 2021 - 2022, which began in September 2021. The subjects in this study were 19th grade students. The research procedure consisted of two cycles with four stages of research starting from planning, implementing, observing, and reflecting. Data collection in this study was carried out using student worksheets, written tests, and documents. The data were analyzed using the percentage formula. The results of this study indicate that the Inquiry Learning Method on the Theme of Obligations and Rights can improve student learning outcomes in grade III SD Negeri 206/X Pandan Jaya which is characterized by increased completeness from pre-cycle $(26 \%)$, cycle I (52\%), cycle II (89\%).
\end{abstract}

Keywords: Learning Outcomes, Problem Based Learning Model.

\begin{abstract}
Abstrak
Penelitian ini bertujuan untuk mengungkapkan informasi dan membahas tentang Penerapan Metode Pembelajaran Inkuiri Dalam Upaya Meningkatkan Hasil Belajar Siswa Pada Tema Kewajiban Dan Hakku Di Kelas III SD Negeri 206/X Pandan Jaya. Penelitian ini termasuk dalam jenis penelitian tindakan kelas (PTK). Penelitian ini dilaksanakan di Penelitian ini dilaksanakan di SD Negeri 206/X Pandan Jaya. Waktu penelitian ini dilaksanakan pada semester ganjil tahun pelajaran 2021 - 2022, yang dimulai pada bulan September 2021. Subjek dalam penelitian ini adalah siswa kelas III yang berjumlah 19 orang. Prosedur penelitian terdiri dari dua siklus dengan empat tahap peneletian mulai dari perencanaan, pelaksanaan, observasi dan refleksi. Pengumpulan data dalam penelitian ini dilakukan dengan menggunakan teknik lembar kerja siswa, tes tertulis, dan dokumen. Data dianalisis dengan menggunakan rumus persentase. Hasil penelitian ini menunjukkan bahwa Melalui Metode Pembelajaran Inkuiri Pada Tema Kewajiban Dan Hakku dapat meningkatkan hasil belajar siswa di kelas III SD Negeri 206/X Pandan Jaya yang ditandai oleh meningkatnya ketuntasan dari pra siklus $(26 \%)$, siklus I (52\%), siklus II $(89 \%)$.
\end{abstract}

Kata kunci: Hasil Belajar, Metode Pembelajaran Inkuiri

Copyright (c) 2021 Elizarita

Corresponding author: Elizarita

Email Address: elizarita@gmail.com (JL. Diponegoro NO. 01, Pandan Jaya, Jambi, Indonesia)

Received 01 December, Accepted 13 December 2021, Published 28 December 2021

\section{PENDAHULUAN}

Pemerintah memajukan ilmu pengetahuan dan teknologi dengan menjunjung tinggi nilai nilai agama dan persatuan bangsa untuk kemajuan peradapan kesejahteraan umat manusia (UUD 1945 Pasal 31 Ayat 5). Menurut UU Sisdiknas No. 20 Tahun 2003 Pasal 3, Pendidikan nasional berfungsi mengembangkan kemampuan dan membentuk watak serta peradaban bangsa yang bermartabat dalam rangka mencerdaskan kehidupan bangsa, bertujuan untuk berkembangnya potensi peserta didik agar 
menjadi manusia yang beriman dan bertakwa kepada Tuhan Yang Mahan Esa, berakhlak mulia, sehat, berilmu, cakap, kreatif, mandiri, dan menjadi warga negara yang demokratis serta bertanggung jawab. Pada kenyataannya, proses pembelajaran di sekolah masih dilakukan dengan cara siswa diminta untuk membaca bacaan kemudian menjawab pertanyaan yang telah disediakan. Proses pembelajaran tersebut cenderung monoton dan kurang bervariasi, sehingga siswa terlihat kurang antusias dalam mengikuti pembelajaran. Oleh karena itu, perlu adanya strategi pembelajaran yang inovatif agar siswa lebih antusias dalam mengikuti pembelajaran dan diharapkan tujuan pembelajaran dapat tercapai secara maksimal.

Namun berdasarkan kenyataan yang ditemukan dalam proses pembelajaran yang sulit untuk dipahami, sehingga berpengaruh terhadap rendahnya hasil belajar siswa. Rendahnya nilai hasil belajar siswa menggambarkan rendahnya tingkat kemampuan siswa. Berdasarkan hasil observasi awal pada kelas III SD Negeri 206/X Pandan Jaya ditemukan bahwa dari 19 guru hanya 5 orang (26\%) yang tuntas belajar dengan KKM 67. Sedangkan sisanya belum tuntas.

Berdasarkan data awal diatas tersebut peneliti tertarik untuk melakukan penelitian tindakan kelas, dalam upaya memperbaiki proses pembelajaran dengan menerapkan metode pembelajaran terbaru. Salah satunya adalah metode pembelajaran inkuiri. Menurut ahmad rohani (1991:36) Inkuiri merupakan struktur event pengajaran atau belajar bersifat ekstetorat atau terbuka sepenuhnya.

Sesuai dengan permasalahan diatas, maka tujuan penelitian tindakan kelas ini adalah untuk mengetahui dan mendapatkan data tentang Penerapan Metode Pembelajaran Inkuiri Dalam Upaya Meningkatkan Hasil Belajar Siswa Pada Tema Kewajiban Dan Hakku Di Kelas III SD Negeri 206/X Pandan Jaya.Pembelajaran mempunyai pengertian yang mirip dengan pengajaran, walaupun mempunyai konotasi yang berbeda. Pembelajaran adalah pemberdayaan potensi peserta didik menjadi kompetensi. Kegiatan pemberdayaan ini tidak dapat berhasil tanpa ada orang yang membantu. Menurut Dimyati \& Mudjiono (Sagala, 2011:62) pembelajaran adalah kegiatan guru secara terprogram dalam desain instruksional, untuk membuat belajar secara aktif, yang menekankan pada penyediaan sumber belajar.

Dalam Undang-Undang No.20 Tahun 2003 Tentang Sistem Pendidikan Nasional pasal 1 ayat 20 dinyatakan bahwa Pembelajaran adalah Proses interaksi peserta didik dengan pendidik dan sumber belajar pada suatu lingkungan belajar. Dapat ditarik kesimpulan bahwa Pembelajaran adalah usaha sadar dari guru untuk membuat siswa belajar, yaitu terjadinya perubahan tingkah laku pada diri siswa yang belajar, dimana perubahan itu dengan didapatkannya kemampuan baru yang berlaku dalam waktu yang relative lama dan karena adanya usaha.

Berdasarkan observasi awal di SD Negeri 168/X Pandan Sejahtera pada kelas IV yang penulis ampu, proses pembelajaran yang dilakukan pada awal semester Ganjil tahun pelajaran 2021/2022 diperoleh fenomena sebagai kurangnya semangat dan antusias siswa dalam belajar sehingga menyebabkan siswa menjadi kurang aktif. Guru juga kurang berusaha dalam mengaitkan materi yang diajarkan dengan situasi dunia nyata anak (guru kurang memberikan kosep nyata). Siswa hanya 
menerima materi pembelajaran yang disampaikan guru tanpa berani mengeluarkan ide-idenya dalam proses pembelajaran, serta proses pembelajaran banyak berpusat kepada guru.

Dari beberapa permasalahan di atas salah satu tindakan yang dapat dilakukan oleh guru adalah dengan menggunakan model pembelajaran yang tepat dalam mengimplementasikan pembelajaran sehingga dapat membantu siswa memahami konsep-konsep dan memudahkan guru mengajarkan konsep-konsep tersebut yang langsung mengaitkan materi konteks pelajaran dengan pengalaman nyata dalam kehidupan sehari-hari.

Salah satu model pembelajaran yang dapat digunakan untuk pembelajaran adalah model Problem Based Learning (PBL). Model Problem Based Learning (PBL) ini menuntut agar siswa mampu dalam memecahkan masalah. Hal ini diperjelas oleh Ramayulis (dalam Istarani, 2012:32) yang mengemukakan bahwa "Pembelajaran berbasis masalah merupakan model pembelajaran dimana peserta didik diharapkan pada suatu kondisi bemasalah, untuk itu peserta didik harus menemukan sejumlah strategi untuk dapat memecahkan masalah tersebut".

Berdasarkan masalah di atas, maka tujuan penelitian adalah untuk mendapatkan informasi tentang Upaya Meningkatan Hasil Belajar Siswa Pada Tema Peduli Terhadap Makhluk Hidup Melalui Model Pembelajaran Problem Based Learning Di Kelas IV SD Negeri 168/X Pandan Sejahtera.

Pembelajaran mempunyai pengertian yang mirip dengan pengajaran, walaupun mempunyai konotasi yang berbeda. Pembelajaran adalah pemberdayaan potensi peserta didik menjadi kompetensi. Kegiatan pemberdayaan ini tidak dapat berhasil tanpa ada orang yang membantu. Menurut Dimyati \& Mudjiono (Sagala, 2011:62) pembelajaran adalah kegiatan guru secara terprogram dalam desain instruksional, untuk membuat belajar secara aktif, yang menekankan pada penyediaan sumber belajar. Dalam Undang-Undang No.20 Tahun 2003 Tentang Sistem Pendidikan Nasional pasal 1 ayat 20 dinyatakan bahwa Pembelajaran adalah Proses interaksi peserta didik dengan pendidik dan sumber belajar pada suatu lingkungan belajar. Dapat ditarik kesimpulan bahwa Pembelajaran adalah usaha sadar dari guru untuk membuat siswa belajar, yaitu terjadinya perubahan tingkah laku pada diri siswa yang belajar, dimana perubahan itu dengan didapatkannya kemampuan baru yang berlaku dalam waktu yang relative lama dan karena adanya usaha.

Berdasarkan observasi awal di SD Negeri 168/X Pandan Sejahtera pada kelas IV yang penulis ampu, proses pembelajaran yang dilakukan pada awal semester Ganjil tahun pelajaran 2021/2022 diperoleh fenomena sebagai kurangnya semangat dan antusias siswa dalam belajar sehingga menyebabkan siswa menjadi kurang aktif. Guru juga kurang berusaha dalam mengaitkan materi yang diajarkan dengan situasi dunia nyata anak (guru kurang memberikan kosep nyata). Siswa hanya menerima materi pembelajaran yang disampaikan guru tanpa berani mengeluarkan ide-idenya dalam proses pembelajaran, serta proses pembelajaran banyak berpusat kepada guru.

Dari beberapa permasalahan di atas salah satu tindakan yang dapat dilakukan oleh guru adalah dengan menggunakan model pembelajaran yang tepat dalam mengimplementasikan pembelajaran sehingga dapat membantu siswa memahami konsep-konsep dan memudahkan guru 
mengajarkan konsep-konsep tersebut yang langsung mengaitkan materi konteks pelajaran dengan pengalaman nyata dalam kehidupan sehari-hari.

Salah satu model pembelajaran yang dapat digunakan untuk pembelajaran adalah model Problem Based Learning (PBL). Model Problem Based Learning (PBL) ini menuntut agar siswa mampu dalam memecahkan masalah. Hal ini diperjelas oleh Ramayulis (dalam Istarani, 2012:32) yang mengemukakan bahwa "Pembelajaran berbasis masalah merupakan model pembelajaran dimana peserta didik diharapkan pada suatu kondisi bemasalah, untuk itu peserta didik harus menemukan sejumlah strategi untuk dapat memecahkan masalah tersebut”.

Berdasarkan masalah di atas, maka tujuan penelitian adalah untuk mendapatkan informasi tentang Upaya Meningkatan Hasil Belajar Siswa Pada Tema Peduli Terhadap Makhluk Hidup Melalui Model Pembelajaran Problem Based Learning Di Kelas IV SD Negeri 168/X Pandan Sejahtera.

Template ini dirancang untuk membantu Penulis dalam mempersiapkan naskah; ini adalah gambaran tepat dari format yang diharapkan oleh editor. Untuk menggunakan template ini, cukup lakukan Save As file MS Word ini ke dokumen Anda, lalu salin dan tempel dokumen Anda di sini. Untuk menyalin dan menempel teks ke template ini, gunakan " Special Paste " dan pilih "Unformatted Text ".

Naskah harus diketik menggunakan perangkat lunak pengolah kata (Microsoft Word atau Open Office). Jenis Tulisan yang digunakan di seluruh makalah adalah Times New Roman ukuran 11 pt. Ukuran kertasnya adalah A4 (yaitu 210 x $297 \mathrm{~mm}$ ), format satu kolom dengan margin $2.5 \mathrm{~cm}$ di bagian atas, bawah, kiri, dan kanan. Garis diberi spasi rata 1,5. Naskah sebaiknya tidak lebih dari 15 halaman. Nomor halaman harus disertakan dalam teks yang terletak di bagian header setiap halaman. Penggunaan kata ganti seperti saya, kami dan sebagainya harus dihindari.

\section{METODE}

Penelitian ini termasuk dalam jenis penelitian tindakan kelas (PTK). Penelitian ini dilaksanakan di Penelitian ini dilaksanakan di SD Negeri 206/X Pandan Jaya. Waktu penelitian ini dilaksanakan pada semester ganjil tahun pelajaran 2021 - 2022, yang dimulai pada bulan September 2021. Subjek dalam penelitian ini adalah siswa kelas III yang berjumlah 19 orang. Prosedur penelitian terdiri dari dua siklus dengan empat tahap peneletian mulai dari perencanaan, pelaksanaan, observasi dan refleksi. Pengumpulan data dalam penelitian ini dilakukan dengan menggunakan teknik lembar kerja siswa, tes tertulis, dan dokumen. Data dianalisis dengan menggunakan rumus persentase.

\section{HASIL DAN DISKUSI}

\section{Paparan Data Pra Siklus}

Kegiatan pengambilan data Pra siklus dilakukan di Kelas III SD Negeri 206/X Pandan Jaya dengan jumlah siswa 19 orang. Pra siklus di lakukan peneliti dengan cara melaksanakan kegiatan pembelajaran pada tema pembelajaran kewajiban dan hakku tanpa menggunakan model Inkuiri. Hasil proses pembelajaran didalam kelas terlihat monoton dan berpusat pada guru, sehingga tingkat 
partisipasi siswa dalam belajar rendah, kurang termotivasi dalam belajar, banyak siswa yang tidak memperhatikan ketika guru menerangkan materi maupun instruksi-instruksi yang akan digunakan nanti oleh siswa dalam membuat latihan ataupun tugas yang akan diberikan nantik, dan banyak siswa yang mengobrol bersama temannya. Kemudian saat guru menyuruh siswa untuk kerja banyak diantara mereka yang tidak mengerti tentang apa yang dilakukan sehingga pada akhir tugas maupun ujian harian banyak hasil belajar siswa yang tidak mencapai KKM.

Hal ini dapat dibuktikan sebelum menerapkan model pembelajaran Inkuiri nilai siswa banyak yang tidak mencapai KKM, hal ini dapat dilihat pada tabel 4.1 dibawah ini:

Tabel 1. Rekapitulasi Hasil Belajar Siswa Pra Siklus

\begin{tabular}{|l|l|}
\hline Jumlah & 1199 \\
\hline Rata -Rata & 63,11 \\
\hline KKM & 67 \\
\hline Jumlah Siswa Yang Tuntas & 5 Orang /26\% \\
\hline Jumlah Siswa Yang Belum Tuntas & 14 Orang /74\% \\
\hline
\end{tabular}

Berdasarkan tabel di atas dapat dijelaskan bahwa sebelum menerapkan Metode Inkuiri pada siswa kelas III SD Negeri 206/X Pandan Jaya di peroleh rata - rata ketuntasan belajar 26\% atau hanya 5 orang siswa dari 19 siswa yang tuntas belajar. Hasil tersebut menunjukkan bahwa pada pra siklus secara klasikal siswa belum tuntas belajar, karena hanya 5 siswa yang memperoleh nilai $\geq 67$ atau hanya sebesar $26 \%$ yang mencapai kriteria ketuntasan minimum (KKM).

Sehingga, masih terdapat 14 dari 19 siswa yang belum tuntas belajar atau sebanyak $74 \%$. Hasil tersebut lebih kecil dari presentase ketuntasan klasikal dalam proses pembelajaran pada materi membaca wacana tulis yang dikehendaki sebesar $80 \%$ siswa harus tuntas belajar. Berdasarkan tabel nilai dan penjelasan nilai pra siklus diatas dapat dilihat lebih jelas pada diagram dibawah ini:

\section{KETUNTASAN BELAJAR SISWA PRA SIKLUS}

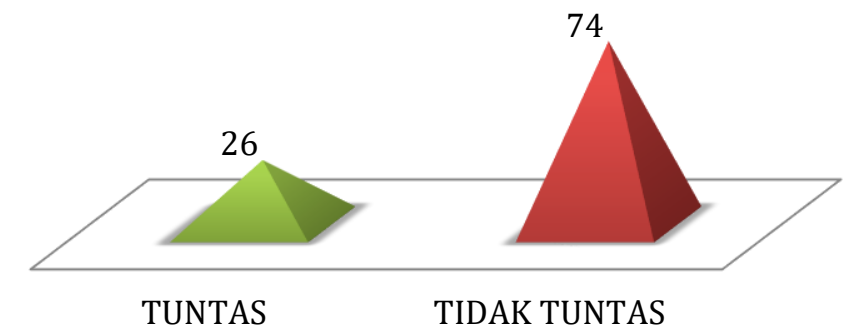

Gambar 1. Diagram Ketuntasan Nilai Pra Siklus

Berdasarkan penjelasan di atas, maka peneliti dibantu oleh teman sejawat melakukan kajian dan telaah metode apa yang akan dipergunakan sebagai dasar pertimbangan memilih strategi pembelajaran yang tepat, dalam upaya melakukan tindakan perbaikan pembelajaran. Setelah mendiskusikan serta berbincang maka peneliti memilih metode Inkuiri dalam pembelajaran. Model ini 
dipergunakan dalam PTK yang akan dilaksanakan pada saat berlangsungnya proses pembelajaran di Kelas pada siswa III SD Negeri 206/X Pandan Jaya, yang diharapkan dapat meningkatkan hasil belajar pada siswa kelas tersebut.

\section{Siklus I}

\section{Perencanaan}

Pada tahap ini peneliti mempersiapkan perangkat pembelajaran yang terdiri dari RPP, silabus, media pembelajaran, lembar aktivitas guru, dokumentasi dan observasi, lembar observasi aktivitas siswa..

\section{Pelaksanaan}

Pertemuan pertama siklus I dilaksanakan pada hari selasa tanggal 21 September 2021 di kelas III dengan jumlah siswa sebayak 19 orang. Adapun materi pembelajaran pada pertemuan pertama ini adalah mengenai kewajiban dan hakku. Pelaksanaan penelitian mengikuti proses pembelajaran yang tertera dalam RPP yang dimulai pada kegiatan pendahuluan, kegiatan inti dan penutup. Pertemuan kedua siklus I dilaksanakan pada hari kamis tanggal 23 September 2021 di kelas III dengan jumlah siswa sebayak 19 orang. Adapun materi pembelajaran pada pertemuan pertama ini adalah mengenai kewajiban dan hakku. Pelaksanaan penelitian mengikuti proses pembelajaran yang tertera dalam RPP yang dimulai pada kegiatan pendahuluan, kegiatan inti dan penutup.

\section{Observasi}

Sesuai dengan tujuan peneliti yaitu Penerapan Metode Pembelajaran Inkuiri Dalam Upaya Meningkatkan Hasil Belajar Siswa Pada Tema Kewajiban Dan Hakku Di Kelas III SD Negeri 206/X Pandan Jaya. Hasil belajar diperoleh dari lembar kerja siswa yang dilakukan pada setiap akhir siklus. Data yang diperoleh berupa angka mengenai hasil belajar yang diperoleh masing-masing siswa pada setiap siklus. Untuk lebih jelasnya hasil belajar siswa dapat dilihat pada tabel dibawah ini:

Tabel 2. Rekapitulasi Hasil Belajar Siswa Siklus I

\begin{tabular}{|l|c|}
\hline Jumlah & 1268 \\
\hline Rata - Rata & 66,74 \\
\hline KKM & 67 \\
\hline Jumlah Siswa Yang Tuntas & 11 Orang /58\% \\
\hline Jumlah Siswa Yang Belum Tuntas & 8 Orang /42\% \\
\hline
\end{tabular}

Dari tabel di atas dapat dijelaskan bahwa Pada siklus I ini di peroleh siswa yang tuntas dalam belajar yaitu 58\% atau 11 siswa dari 19 siswa yang tuntas belajar. Hasil tersebut menunjukkan bahwa pada siklus I secara klasikal peserta didik belum tuntas belajar secara keseluruhan, karena target yang diinginkan $80 \%$. Sedangkan pada siklus I hanya 11 siswa yang memperoleh nilai $\geq 67$ atau hanya sebesar 58\% yang mencapai kriteria ketuntasan minimum (KKM). Sehingga, masih terdapat 8 dari 19 siswa yang belum tuntas belajar atau sebanyak $42 \%$. Hasil masih kurang dari target yang diinginkan yaitu sebesar $80 \%$. Berdasarkan tabel nilai dan penjelasan nilai dari siklus I diatas dapat dilihat lebih jelas pada diagram dibawah ini: 


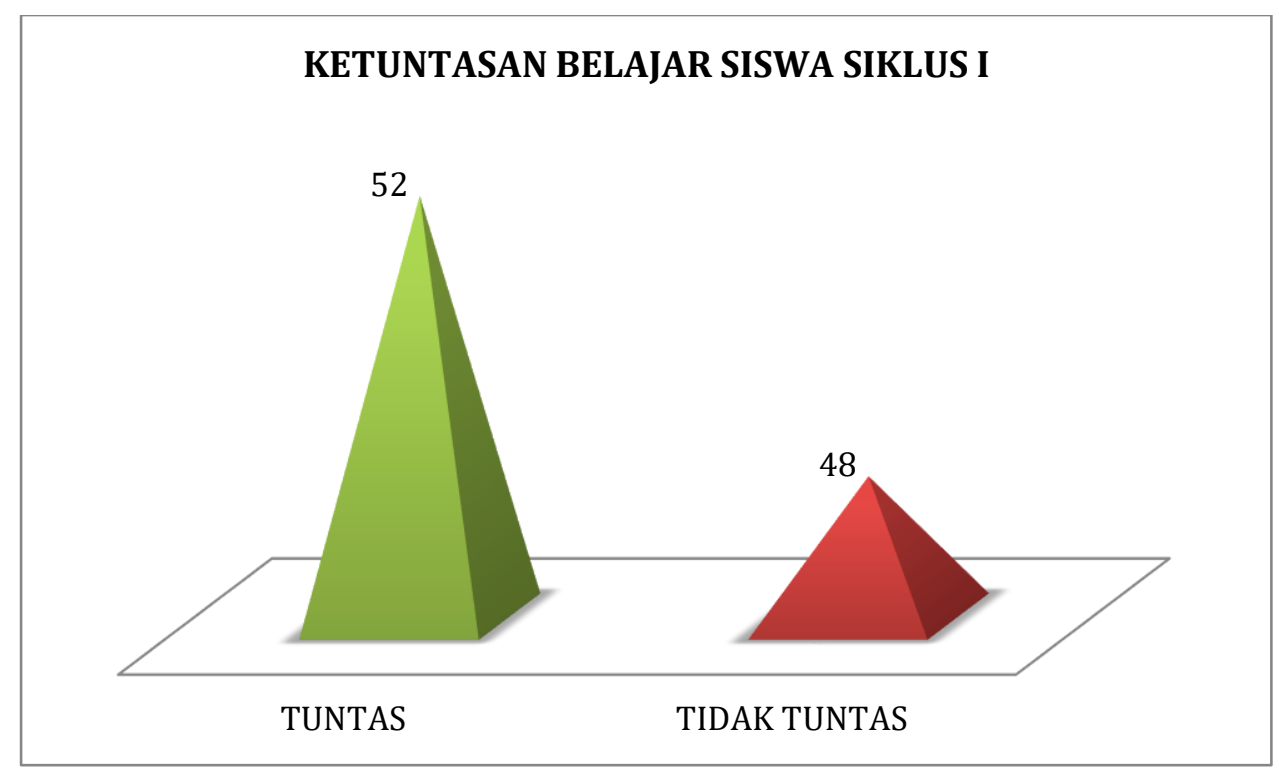

Gambar 2. Diagram Ketuntasan Nilai Siklus I

Berdasarkan diagram di atas menyatakan bahwa hasil belajar siswa dalam belajar masih perlu perbaikan. Banyaknya anak yang berada pada kategori kurang baik yang berjumlah 8 orang dari 19 siswa, karena belum mencapai target ketuntasan yang diinginkan yaitu $80 \%$, untuk itu perlu di adakan lanjutan pada siklus ke II.

\section{Refleksi}

Dalam tahap refeleksi ini guru mata pelajaran dibantu oleh observer menyampaikan bahawa guru kurang mempersiapkan diri dengan alat-alat/ media dalam rangka melengkapi bahan yang dibutuhkan seperti laptop, infokus, buku sumber dan lainnya yang berguna untuk menambah wawasan siswa dalam memahami materi kewajiban dan hakku. Seharusnya guru harus mempersiapkan bahan, alat, sumber belajar saat berada didalam kelas sehingga siswa bisa materi yang dipelajari. Guru harus mampu membimbing siswa yang mempunyai kemampuan rendah dan kurang dalam menguasai materi, dan harus memberikan pengulangan pada materi yang diajarkan yang mungkin sulit atau kurang mengerti siswa dan lainnya, selalu memberikan motivasi atau semangat kepada siswa untuk selalu siap saat siswa melakukan pembelajaran. Dari masalahan diatas perlu dilakukan siklus selanjutnya, yaitu siklus ke II.

\section{Siklus II}

\section{Perencanaan}

Pada tahap ini peneliti mempersiapkan perangkat pembelajaran yang terdiri dari RPP, silabus, media pembelajaran, lembar aktivitas guru, dokumentasi dan observasi, lembar observasi aktivitas peserta didik untuk siklus II

\section{Pelaksanaan}

Pertemuan pertama siklus II dilaksanakan pada hari sabtu tanggal 25 September 2021 di kelas III dengan jumlah siswa sebayak 19 orang. Adapun materi pembelajaran pada pertemuan pertama ini 
adalah mengenai kewajiban dan hakku. Pelaksanaan penelitian mengikuti proses pembelajaran yang tertera dalam RPP yang dimulai pada kegiatan pendahuluan, kegiatan inti dan penutup.

Pertemuan kedua siklus II dilaksanakan pada hari selasa tanggal 28 September 2021 di kelas III dengan jumlah siswa sebayak 19 orang. Adapun materi pembelajaran pada pertemuan pertama ini adalah mengenai kewajiban dan hakku. Pelaksanaan penelitian mengikuti proses pembelajaran yang tertera dalam RPP yang dimulai pada kegiatan pendahuluan, kegiatan inti dan penutup.

\section{Observasi}

Sesuai dengan tujuan peneliti yaitu Penerapan Metode Pembelajaran Inkuiri Dalam Upaya Meningkatkan Hasil Belajar Siswa Pada Tema Kewajiban Dan Hakku Di Kelas III SD Negeri 206/X Pandan Jaya. Hasil belajar diperoleh dari lembar kerja siswa yang dilakukan pada setiap akhir siklus. Data yang diperoleh berupa angka mengenai hasil belajar yang diperoleh masing-masing siswa pada setiap siklus. Untuk lebih jelasnya hasil belajar siswa dapat dilihat pada tabel dibawah ini:

Tabel 3. Rekapitulasi Hasil Belajar Siswa Siklus II

\begin{tabular}{|l|c|}
\hline Jumlah & 1332 \\
\hline Rata -Rata & 70,11 \\
\hline KKM & 67 \\
\hline Jumlah Siswa Yang Tuntas & 17 Orang /89\% \\
\hline Jumlah Siswa Yang Belum Tuntas & 2 Orang /11\% \\
\hline
\end{tabular}

Dari tabel di atas dapat dijelaskan bahwa Pada siklus II ini di peroleh rata - rata siswa yang tuntas belajar sebesar $89 \%$ atau 17 siswa dari 25 siswa yang tuntas belajar. Hasil tersebut menunjukkan bahwa pada siklus II secara klasikal sudah baik, karena hanya 2 siswa yang memperoleh nilai kurang dari 67 atau hanya sebesar $11 \%$ yang belum tuntas. Berdasarkan tabel nilai dan penjelasan nilai dari siklus II diatas dapat dilihat lebih jelas pada diagram dibawah ini:

\section{KETUNTASAN BELAJAR SISWA SIKLUS II}

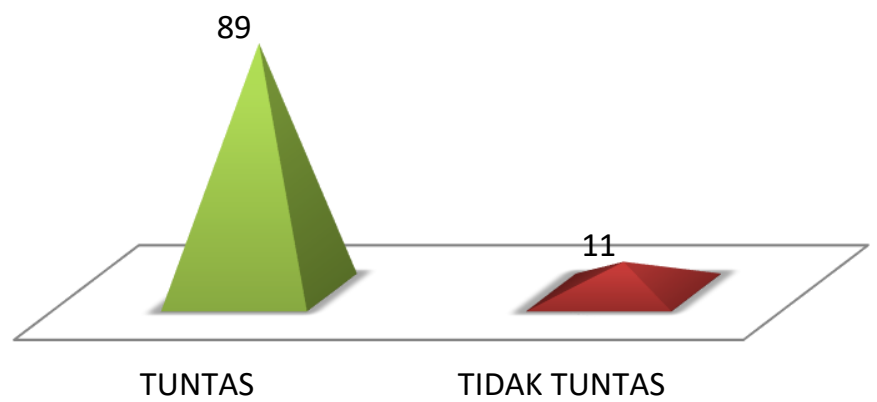

Gambar 3. Diagram Ketuntasan Nilai Siklus I

Berdasarkan grafik di atas menjelaskan bahwa hasil belajar siswa dalam pembelajaran sudah baik. Hal itu ditandai dengan Banyaknya siswa yang berada pada kategori tuntas yaitu ada 17 siswa dari 19 siswa dengan persentase ketuntasan 89\%, dengan banyaknya siswa tuntas pada siklus ke II maka penelitian ini telah berhasil dan tidak dilanjutkan pada siklus berikutnya. 


\section{Refeleksi}

Dalam tahap refeleksi ini guru kelas dibantu oleh observer menyampaikan bahwa guru sudah memperbaiki apa kekurangan dan masalah yang ditemukan pada siklus I seperti mempersiapkan diri dengan alat-alat/ media dalam rangka melengkapi bahan yang dibutuhkan seperti laptop,infokus, buku sumber dan lainnya yang berguna untuk menambah wawasan siswa dalam memahami materi membaca wacana tulis dalam pembelajaran.

Guru juga sudah mempersiapkan bahan, alat, sumber belajar saat berada didalam kelas sehingga siswa bisa memahami tema kewajiban dan hakku. Guru sudah membimbing siswa yang mempunyai kemampuan rendah dalam memahami pembelajaran. Dari masalahan diatas maka siklus ini tidak perlu dilanjutkan ke siklus berikutnya.

\section{Diskusi}

Dalam pembelajaran dengan menggunakan model pembelajaran inkuiri ini siswa diarahkan menemukan konsep dengan bantuan LKS melalui kegiatan-kegiatan diskusi. Dalam pembelajaran, guru membimbing siswa berada disamping mereka yang membutuhkan bimbingan, membuat siswa merasa puas dan senang dan merasa diperhatikan sehingga siswa merasa bersemangat belajar.

Perbandingan persentase pencapaian KKM pada pra siklus, siklus I dan siklus II adalah sebesar 26\%, 52\% dan 89\%. Dari peningkatan hasil belajar siswa setiap siklus, dapat disimpulkan bahwa penerapan model pembelajaran Inkuiri, dapat meningkatkan hasil belajar siswa pada tema kewajiban dan hakku di kelas III SD Negeri 206/X Pandan Jaya. Ini sesuai dengan Bab IV Pasal 19 Peraturan Pemerintah No. 19 Tahun 2005 dikatakan bahwa proses pembelajaran pada satuan pendidikan diselenggarakan secara interaktif, inspiratif, menyenangkan, menantang, memotivasi siswa untuk berpartisipasi aktif, serta memberikan ruang yang cukup bagi prakarsa, kreativitas, dan kemandirian sesuai dengan bakat, minat, perkembangan fisik, serta psikologis siswa. Untuk lebih jelasnya mengenai peningkatan hasil belajar siswa dapat dilihat pada diagram di bawah ini:

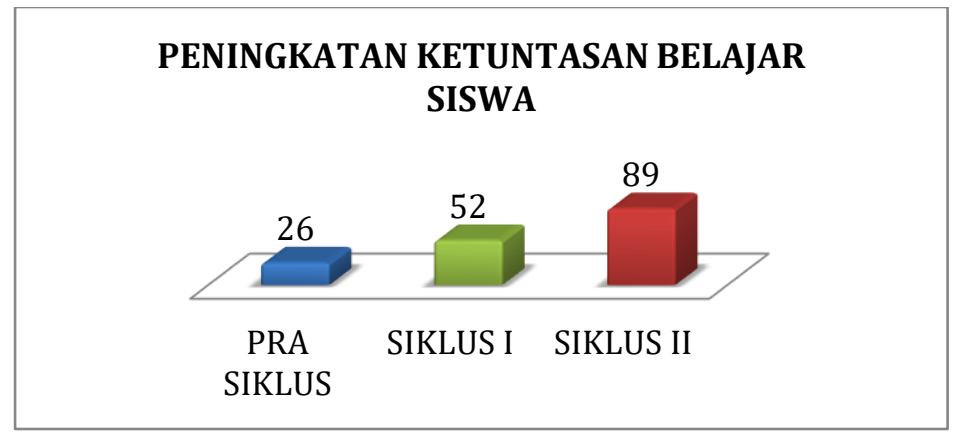

Gambar 4. Peningkatan Ketuntasan Belajar Siswa

\section{KESIMPULAN}

Dari hasil kegiatan pembelajaran yang telah dilakukan selama dua siklus, dan berdasarkan seluruh pembahasan serta analisis yang telah dilakukan dapat disimpulkan sebagai berikut: 
1. Pembelajaran pada tema kewajiban dan hakku dengan Metode pembelajaran Inkuiri memiliki dampak positif dalam meningkatkan hasil belajar siswa yang ditandai dengan peningkatan ketuntasan belajar siswa dalam setiap siklus.

2. Penerapan Metode pembelajaran Inkuiri mempunyai pengaruh positif, yaitu dapat meningkatkan hasil belajar siswa yang ditunjukan dengan rata-rata hasil belajar siswa yang menyatakan bahwa siswa tertarik dan berminat dengan Metode pembelajaran Inkuiri sehingga mereka menjadi termotivasi dalam belajar dan berlatih.

Dari hasil penelitian yang diperoleh dari uraian sebelumnya agar proses pembelajaran lebih efektif dan lebih memberikan hasil yang optimal bagi siswa, maka peneliti menyarankan:

1. Untuk melaksanakan Metode Inkuiri memerlukan persiapan yang cukup matang, sehingga guru harus mampu menentukan atau memilih topik yang benar-benar bisa diterapkan dengan Metode pembelajaran Inkuiri dalam proses belajar mengajar sehingga diperoleh hasil yang maksimal.

2. Dalam rangka meningkatkan hasil belajar siswa, guru hendaknya lebih sering memberi latihan kepada siswa dengan berbagai metode pengajaran, walau dalam taraf yang sederhana, dimana siswa nantinya dapat menemukan pengetahuan baru, memperoleh konsep dan keterampilan, sehingga siswa berhasil atau mampu memecahkan masalah-masalah yang dihadapinya.

3. Perlu adanya penelitian yang lebih lanjut, karena hasil penelitian ini hanya dilakukan di kelas III SD Negeri 206/X Pandan Jaya tahun pelajaran 2021/2022.

4. Untuk penelitian yang serupa hendaknya dilakukan perbaikan-perbaikan agar diperoleh hasil yang lebih baik.

\section{REFERENSI}

Agus, Suprijono. (2012). Cooperative Learning: Teori dan Aplikasi Paikem. Yogyakarta: Pustaka Pelajar.

Ahmad Rohani \& Abu Ahmadi. (1991). Pengelolaan Pengajaran. Jakarta: Rineka Cipta.

Arikunto, Suharsimi. (1992). Prosedur Penelitian Suatu Pendekatan Praktik. Jakarta: PT Rineka Cipta. Fathurrahman, Muhammad dan Sulistyorini. (2013). Belajar \& Pembelajaran, Meningkatkan Mutu Pembelajaran Sesuai Standar Nasional. Yogyakarta: Teras.

Gagne. Robert M. (1989). Kondisi Belajar dan Teori Pembelajaran. (Munandir). PAU Dirjen Dikti Depdikbud. Jakarta.

Iskandarwassid, dan H. Dadang Sunendar. (2009). Strategi Pembelajaran Bahasa. Bandung: PT. Remaja Rosdakarya.

Mulyasa. (2011). Manajemen Berbasis Sekolah, Konsep, strategi dan Implementasi. Bandung: PT. Remaja Rosdakarya.

Nana Sudjana. (2002). Penilaian Hasil Proses Belajar Mengajar. Bandung: Remaja Rosdakarya. Nasution (2003). Metode Penelitian Naturalistik Kualitatif. Bandung: Tarsito 
Pribadi, Benny A. (2011). Model Desain Assure untuk Mendesain Pembelajaran Sukses. Jakarta: Dian Rakyat.

Sanjaya, W. (2006). Strategi Pembelajaran. Jakarta: Kencana Prenada Media Group.

Slameto. (2010). Belajar dan faktor-faktor yang Mempengaruhinya. Jakarta: PT. Rineka Cipta

Trianto. (2012). Model Pembelajaran Terpadu. (Jakarta: PT Bumi Aksara).

Uno B. Hamzah. (2011). Teori Motivasi dan Pengukurannya Analisis di Bidang Pendidikan, Jakarta: PT. Bumi Aksara

UUD 1945 Pasal 31 Ayat 5

UU Sisdiknas No. 20 Tahun 2003 Pasal 3 